\title{
The Development of Project-Based Innovative Learning Resources for Teaching Organic Analytical Chemistry
}

\author{
Dessy Novianty Pakpahan ${ }^{1}$, Manihar Situmorang ${ }^{2 *}$, Marham Sitorus ${ }^{2}$, and Saronom \\ Silaban $^{2}$ \\ ${ }^{1}$ Department of Chemistry Education, Post Graduate Study Program (Program Pascasarjana), Universitas Negeri \\ Medan, Medan, North Sumatera, Indonesia, 20221 \\ ${ }^{2}$ Department of Chemistry, Faculty of Mathematics and Natural Sciences (FMIPA), Universitas Negeri Medan, \\ Medan, North Sumatera, Indonesia, 20221 \\ *Corresponding E-mail: msitumorang@unimed.ac.id
}

\begin{abstract}
An Organic Analytical Chemistry course is very important for prospective chemists because it builds competence in the analysis of organic compounds. This study aims to develop project-based innovative learning resources to guide students to study Organic Analytical Chemistry. The research was conducted by following the ADDIE model to develop learning resource for undergraduate students. The study involve 35 students of the Chemistry Study Program at 2020-2021 academic year. The results showed that innovative learning resource has been developed to facilitate students to learn the analysis of organic compounds. The implementation of learning resources has proven to be effective in guiding students in studying Organic Analytical Chemistry. It can facilitate students' independent learning in planning and carrying out their own projects for the determination of flavonoid compounds from real samples. The skills in the field of organic compound analysis including isolation, purification and identification of flavonoid compounds are achieved. Student learning outcomes are very good $(\mathrm{M}=87.89 \pm 1.86)$, successively the portfolio of project proposals $(\mathrm{M}=$ $83.14 \pm 2.06)$, project reports $(M=90.37 \pm 1.05)$, and evaluation test $(M=90.17 \pm 2.48)$. It is concluded that project-based innovative learning resources are very appropriate to be used for teaching Organic Analytical Chemistry.
\end{abstract}

Keywords: Project Based Innovative, Learning, Organic Analytical Chemistry.

\section{INTRODUCTION}

The organic analytical chemistry course is very important for students of the Chemistry Department because by studying this course students will gain experience in the field of organic compound analysis, which is one of the competencies that must be possessed by a chemist [1-2]. This course requires knowledge and skills in the analysis of organic compounds that can be obtained through lectures and laboratory activities. The problem faced by students is that it is difficult to study the analysis of organic compounds because of limitations in learning resources to study the analysis of organic compounds [3]. The available learning resources are only generic in explaining Organic Chemistry as a result, knowledge and skills in organic analysis are difficult to achieve. Another factor, namely the outbreak of a disease caused by the corona virus (Covid-19) since 2019, causes organic analysis learning to be carried out only in one direction, and as a result it is difficult for students to achieve competence in knowledge and skills, because there is a prohibition for students to work in laboratories. The lecture system during the Covid-19 pandemic was carried out online [4]. Students do not carry out laboratory activities to limit distance in accordance with the health protocols applicable at the university with the aim of breaking the chain of virus transmission. Laboratory activities are only carried out for a short period of time following strict health protocols. To overcome this problem, it is necessary to improve learning, namely through the use of innovative learning resources to facilitate active learning students to achieve competence in the field of organic compound analysis [5$6]$. 
Research has been carried out to facilitate student learning, including the application of learning methods and strategies, learning innovation, the use of media and multimedia and the selection of actions [7]. Learning innovation is very relevant to create new and enjoyable learning experiences for students. Learning innovation by providing innovative learning resources has been proven to improve learning outcomes. Project-based learning has also been proven to be effective in facilitating students to learn actively in achieving their competencies. Project-based learning allows students to enhance their learning experience in the areas of analysis and problem solving [8]. Development of innovative learning resources by integrating projects and combining them with relevant multimedia to be used in learning during the COVID-19 pandemic. Through this learning, students can improve their skills and knowledge of skills such as creative thinking, practice solving problems found in the field of organic chemistry.

Isolation and identification of organic compounds are the main topics in the Organic Analytical Chemistry course [9-10]. Various organic compounds contained in samples of plants and organisms can be analyzed to obtain potential organic compounds for medicinal or industrial raw materials. Therefore, knowledge about the isolation of organic compounds must be mastered by students. Skills in finding organic compounds from medicinal plants need to be mastered by chemists who work in the organic field. Flavonoid compounds are one of the organic compounds contained in organic samples, and some of them have been proven in phytochemical studies to be efficacious as medicinal raw materials [1113]. Thus, the analysis of organic compounds must be carried out properly to obtain the target flavonoid compounds. This study aims to develop project-based innovative learning resources with an emphasis on flavonoid analysis, which will be used by students in studying the analysis of organic compounds, as well as to facilitate active learning for students to improve student learning outcomes in the teaching of Organic Analytical Chemistry. Learning resources will be used in integrated learning during the Covid-19 pandemic to increase competence in the field of organic compound analysis.

\section{RESEARCH METHOD}

\subsection{Research design}

This research is a development-research following the ADDIE (Analysis- Design- DevelopmentImplementation- Evaluation) model, including analysis of learning resource needs according to the Indonesian National Qualifications Framework [Kerangka Kualifikasi Nasional Indonesia, KKNI)-oriented curriculum, developing project-based learning resources for universities in the Organic Analytical Chemistry course, compiled project packages for the isolation and identification of flavonoid compounds. Learning resources are then standardized using experts to see the feasibility of learning resources following the criteria for teaching materials set by the National Education Standards Agency [Badan Standar Nasional Pendidikan, BSNP), and continued with the implementation of learning resources for teaching Organic Analytical Chemistry.

\subsection{Population and samples}

The population in this study were all students of the Department of Chemistry, FMIPA, Medan State University (UNIMED), who studied the Organic Analytical Chemistry course. The sample used includes 35 students who are enrolled in the Organic Analytical Chemistry course in the Even Semester of the 2020-2021 academic year. Student participation in this research has previously received approval from each student, in accordance with the code of ethics for research in the field of social sciences that applies at the State University of Medan.

\subsection{Research procedures}

The implementation of the research begins with an analysis of learning resource needs for Organic Analytical Chemistry courses according to the KKNI curriculum, followed by standardization, and implementation of learning resources for teaching Organic Analytical Chemistry. The needs analysis stage is carried out to analyze available organic analysis learning resources and used by students as a handbook. The planning stage is carried out to design project-based learning resources for purification isolation materials and identification of flavonoid group compounds. Learning resources are packaged in the form of textbooks (hard copy) and electronic books (e-books). The development of learning resources in the form of multimedia and learning videos is also carried out which is adaptive to online learning. The whole package of learning resources is designed according to the need to fulfill competence in analyzing organic compounds as desired in the KKNI curriculum [14]. Learning resources in the form of sample project packages, video examples of project implementation, observation sheets, compiling templates for project proposals and project reports, criteria for plant samples containing flavonoids, and hyperlinks on websites that are believed to be packaged as innovative learning resources. Learning resources are then standardized using experts following the National Education Standards Agency [Badan Standart Nasional Pendidikan, BSNP] criteria following the procedures described in previous studies [15]. Students' mastery of organic compound analysis material is measured through an initial evaluation (pretest) and followed by lectures via zoom to provide information on the stages of lecture implementation and project assignments, as well as to explain the use of the University Networked Learning System [Sistem Pembelajaran Dalam Jaringan Universitas, SIPDA), technical assignment collection, implementation of exams, and the scoring rubric. 
Implementation of innovative learning resources for teaching Organic Analytical Chemistry is the main target of this research with the aim of increasing student competence in the field of organic compound analysis [16]. Before learning, a pretest was conducted to see the students' initial ability in organic compound analysis material, conducted online. All learning resource packages, announcements of lectures and project implementation, collection of project assignments, and exams are carried out through the SIPDA toolkit. Lectures are carried out in an integrated learning (blended learning), which is a combination of online and offline teaching. online learning is used to deliver teaching materials using zoom meetings and SIPDA. The implementation of the project is carried out in an offline laboratory with laboratory entry settings strictly adhering to health protocols to break the chain of the spread of the corona virus [17]. Arrangements for students to carry out projects in the laboratory are ordered based on the speed with which students complete project proposals at SIPDA which are approved by the lecturer or tutor. All stages of work in the laboratory are under the supervision of a team of lecturers, students taking turns are allowed to take turns in small numbers, until all students have a turn to do their projects. Announcements for the deadline for submitting assignments, project assessment rubrics, and grades obtained by students from assignments carried out are all available at SIPDA. At the end of the lesson, an online evaluation of learning outcomes (posttest) is carried out.

\subsection{Research Data Analysis}

The research data consisted of respondents' opinions, observations, subjective assessments, and objective assessments. Respondents' opinions were collected using a Likert scale questionnaire, with four levels of answers on the assessment criteria scale, the highest with a score of (4) to the lowest with a score of (1). The results of observations were carried out using an observation sheet with a checklist on the choice of very skilled to unskilled criteria. Subjective assessment is carried out to provide project scores (proposals and reports) using the assignment assessment rubric, then the scores are converted to scores with a rating scale of $0-100$. The objective value is obtained based on the student's ability to answer standard evaluation questions, then the score obtained by the student is converted into a value with a scale of $0-100$.

\section{RESULTS AND DISCUSSION}

\subsection{Project-Based Innovative Learning Resource Package}

Innovative learning resources based and project assignments for the teaching of Organic Analytical Chemistry have been developed in accordance with the KKNI curriculum. The learning package has been designed to adapt to the Covid-19 pandemic situation which emphasizes the implementation of blended learning. Learning resources are designed in such a way as to guide students in active learning, with the aim of increasing knowledge and skills to achieve competence in the field of organic compound analysis. Descriptions of learning resources developed together with their completeness are summarized in Table 1. The project package consists of three titles with the aim of training students to apply the theoretical principles of Organic Analytical Chemistry into practice to isolate, separate, purify and identify flavonoid compounds from various types of plant leaves. This project package is used as an example so that students can determine and select samples of medicinal plants suspected of containing flavonoids. A brief description of the project and multimedia package is summarized in Table 2. These learning resources have been standardized and assigned to be standard, and appropriate to be used in teaching Organic Analytical Chemistry.

\subsection{Implementation in Teaching Organic Analytical Chemistry}

Prior to the Organic Analytical Chemistry lecture, an initial evaluation was carried out, followed by an explanation of the stages of the seven-week lecture. Students' knowledge of the results of the pretest is low (see Table 3 data). Implementation of learning resources for teaching organic chemistry is done by blended learning. Chemical material is delivered briefly using zoom meetings, online project assignments using SIPDA, and offline project implementation in the laboratory. The timing of project implementation is very strict and supervised because it must comply with health protocols.

The main objective of implementing innovative learning using project-based learning resources is that students achieve competence in the field of organic compound analysis. Competency achievement can be seen from the students' mastery in the analysis of organic compounds including skills and knowledge. All available learning resources and assignment instructions have been used optimally by students in studying organic analysis as indicated by the recorded use of SIPDA indicators. The results of the uploaded project assignment assessment (Proposals and Reports) are summarized in Table 4. Students have been able to prepare project proposals well $(\mathrm{M}=83.10 \pm 2.79)$. The project proposal has been well implemented for the isolation of flavonoid compounds. Student achievement based on the project implementation report $(\mathrm{M}=90.80 \pm 2.64)$ was classified as very high.

Observations on project implementation have been carried out. Since the implementation of the project in the laboratory was held during the Covid-19 pandemic, all students were aware and obedient to the health protocol. Students do the project properly, keep their distance, do the work safety and health properly. Guidance and supervision are carried out during project implementation in the laboratory to ensure that students understand the 
isolation and identification steps of flavonoid compounds.

Table 1. Packages of innovative project-based learning resources integrated with multimedia for teaching Organic Analytical Chemistry

\begin{tabular}{|c|c|c|c|}
\hline No & Sub-Topic & Learning Resources Innovation & Supplements \\
\hline 1 & $\begin{array}{l}\text { Classification of } \\
\text { Natural Organic } \\
\text { Compounds }\end{array}$ & $\begin{array}{l}\text { Learning materials for the classification of natural organic } \\
\text { compounds, equipped with learning videos and hyperlinks on the } \\
\text { appropriate website }\end{array}$ & $\begin{array}{l}\text { Multimedia for Online } \\
\text { Learning }\end{array}$ \\
\hline 2 & Flavonoid & $\begin{array}{l}\text { Learning materials about flavonoid compounds are equipped } \\
\text { with journal supplements that are relevant to the analysis of } \\
\text { flavonoid compounds }\end{array}$ & $\begin{array}{l}\text { Multimedia for Online } \\
\text { Learning }\end{array}$ \\
\hline 3 & $\begin{array}{l}\text { Isolation } \\
\text { Techniques of } \\
\text { Natural Organic } \\
\text { Compounds }\end{array}$ & $\begin{array}{l}\text { Learning materials regarding the techniques used in isolating } \\
\text { organic compounds from natural materials and equipped with the } \\
\text { latest scientific journals on isolation of flavonoids by extraction } \\
\text { using soxhlet, purification techniques, identification and } \\
\text { confirmation of target compounds. }\end{array}$ & $\begin{array}{l}\text { Project } 1 \text { Isolation of } \\
\text { flavonoids by } \\
\text { soxhletation }\end{array}$ \\
\hline 4 & $\begin{array}{l}\text { Flavanoid } \\
\text { Compound } \\
\text { Isolation and } \\
\text { Identification } \\
\text { Laboratory Work } \\
\text { Project }\end{array}$ & $\begin{array}{l}\text { Materials on laboratory work projects for the isolation and } \\
\text { identification of flavonoid compounds from plant samples, } \\
\text { accompanied by examples of implementation projects to isolate, } \\
\text { purify and identify flavonoid compounds from plant raw } \\
\text { materials. The project package is used as a guide for students in } \\
\text { carrying out project activities starting from assembling } \\
\text { equipment, providing solutions, sample treatment, flavonoid } \\
\text { compound analysis steps according to plant targets that have } \\
\text { been chosen by students, and templates for preparing project } \\
\text { reports. }\end{array}$ & $\begin{array}{l}\text { Sample projects } \\
\text { (Project } 2 \text { and Project } \\
\text { 3) for the isolation, } \\
\text { purification and } \\
\text { identification of } \\
\text { flavonoid compounds } \\
\text { from various } \\
\text { medicinal plants }\end{array}$ \\
\hline
\end{tabular}

Table 2 Packages of mini projects, multimedia tools and observation sheets as examples of the implementation of flavonoid compound analysis

\begin{tabular}{|c|c|c|c|}
\hline No & Project title & Brief description of the mini-project and multimedi & $\begin{array}{c}\text { Types of } \\
\text { documents }\end{array}$ \\
\hline 1 & $\begin{array}{l}\text { Project } 1 \text { Isolation of } \\
\text { flavonoids by } \\
\text { soxhletation }\end{array}$ & $\begin{array}{l}\text { Based learning resources are arranged consisting of objectives, } \\
\text { theoretical basis, work procedures (assembly of equipment, chemicals } \\
\text { and materials, sample analysis, observation, purification, qualitative } \\
\text { identification and quantitative analysis). All analysis steps are shown } \\
\text { in video form. }\end{array}$ & $\begin{array}{l}\text { Videos, } \\
\text { Observation } \\
\text { Worksheets, and } \\
\text { Assessment } \\
\text { Rubrics }\end{array}$ \\
\hline 2 & $\begin{array}{l}\text { Project } 2 \text { : Separation, } \\
\text { purification and } \\
\text { identification of } \\
\text { flavonoids from bay } \\
\text { leaves }\end{array}$ & $\begin{array}{l}\text { Example project for analysis of flavonoids from bay leaves. Packaged } \\
\text { learning resources consist of objectives, theoretical basis, work } \\
\text { procedures (assembly of equipment, chemicals and materials, } \\
\text { procedures for providing and analyzing samples, observation, } \\
\text { purification, identification). All analysis steps are shown in video. }\end{array}$ & $\begin{array}{l}\text { Videos, } \\
\text { Observation } \\
\text { Worksheets, and } \\
\text { Assessment } \\
\text { Rubrics }\end{array}$ \\
\hline 3 & $\begin{array}{l}\text { Project } 3 \text { Separation, } \\
\text { purification and } \\
\text { identification of } \\
\text { flavonoids from black } \\
\text { tea leaves }\end{array}$ & $\begin{array}{l}\text { Sample project for flavonoid analysis from black tea samples. } \\
\text { Packaged learning resources consist of objectives, theoretical basis, } \\
\text { work procedures (assembly of equipment, chemicals and materials, } \\
\text { procedures for preparation and analysis of samples, observation, } \\
\text { purification, identification). The project implementation steps are } \\
\text { demonstrated in the form of a video }\end{array}$ & $\begin{array}{l}\text { Videos, } \\
\text { Observation } \\
\text { Worksheets, } \\
\text { Assessment } \\
\text { Rubrics }\end{array}$ \\
\hline
\end{tabular}

Table 3. Student achievements based on a portfolio of proposals and project reports

\begin{tabular}{llcc}
\hline \multirow{2}{*}{ No } & \multicolumn{1}{c}{ Assessment components } & \multicolumn{2}{c}{ Student achievements } \\
\cline { 3 - 4 } & \multicolumn{1}{c}{$\begin{array}{l}\text { Project proposals } \\
\text { Project topic and suitability of project content (project } \\
\text { objectives) }\end{array}$} & $83.14 \pm 3.05$ & $91.34 \pm 1.99$ \\
$\begin{array}{l}\text { Project systematics (format, project components, reference } \\
\text { updates) }\end{array}$ & $83.03 \pm 2.98$ & $89.94 \pm 2.98$ \\
3 & $\begin{array}{l}\text { Procedure and equipment (equipment, solution, sample target } \\
\text { selection) }\end{array}$ & $83.14 \pm 2.34$ & $90.08 \pm 3.54$ \\
4 & $\begin{array}{l}\text { Project reports (the systematics, project implementation, } \\
\text { activities and observations, presentation of results, disclosure } \\
\text { of findings, discussions, conclusions, documentation) }\end{array}$ & - & $91.82 \pm 2.05$ \\
\hline & Average & $83.10 \pm 2.79$ & $90.80 \pm 2.64$ \\
\hline
\end{tabular}


Table 4 Student learning outcomes based on project portfolio assessment, practicum, and learning evaluation.

\begin{tabular}{llc}
\hline No & Assessment of learning outcomes & Student achievement \\
\hline 1 & Preliminary test (pretest) & $44.11 \pm 5.53$ \\
2 & Project proposal* $^{*}$ & $83.10 \pm 2.79$ \\
3 & Project final report* & $90.37 \pm 1.05$ \\
4 & Final exam (posttest) & $90.80 \pm 2.64$ \\
\hline & Average** & $88.09 \pm 2.16$ \\
\hline
\end{tabular}

* Obtained from results in Table 4

** Average of the projects proposal, reports and final evaluation

The psychomotor skills obtained by students include the skills of assembling equipment, making solutions, implementing projects, observing and recording results, analyzing and reporting results, all of which have been fulfilled properly.

Student competence in the field of organic compound analysis has been achieved, which is seen from the learning outcomes that have been achieved by students as summarized in Table 4. Student learning outcomes sequentially for ability to plan projects $(\mathrm{M}=83.10 \pm 2.79)$, ability to carry out and report implementation projects $(\mathrm{M}=90.37 \pm 1.05)$, and the final evaluation of learning outcomes $(\mathrm{M}=90.80 \pm 2.64)$, all classified as very high $(\mathrm{M}=88.09 \pm 2.16)$.

\subsection{Discussion}

Knowledge and skills in the field of organic compound analysis become one of the competencies required by a chemist. Thus, this competency must be possessed by students before completing their studies [18]. During the current corona virus outbreak, it is very difficult for students to achieve competence in the field of analytical chemistry because they must combine knowledge and skills, where project-based learning as found in this study is the right choice. The implementation of project-based learning resources is proven to motivate students to learn actively and independently, as well as to improve their knowledge and skills. Project-based innovative learning resources are very effective when equipped with project examples in the form of videos that make it easier for students to learn independently. The learning resource package that is prepared in accordance with the KKNI is in accordance with the needs of students as prospective chemists $[19,20]$. Standard innovative learning resource packages are very effective in helping students learn Organic Analytical Chemistry. Through the use of learning resources to make student learning activities meaningful, they can isolate and identify flavonoid compounds according to the target sample [21]. Direct student involvement in planning and implementing projects makes students appreciate the project implementation process, so that knowledge and skills in the field of organic analysis have been obtained. Students are accustomed to handling plant samples as a source of flavonoid compounds which are widely used as raw materials for medicine and industry.

Innovative learning resource packages from research have proven to be effective in facilitating students to study the analysis of organic compounds during the Covid-19 pandemic. Student mastery in the field of organic compound analysis is classified as very good, as evidenced by the high scores obtained from activities and final exams. The availability of innovative learning resources has succeeded in making students work efficiently in a short period of time in the laboratory, in accordance with lecture instructions during the Covid-19 pandemic [22]. All steps of isolation and identification of flavonoid compounds have been carried out correctly. Students have learned from examples of projects that are packaged in the form of multimedia and videos. Isolation techniques and identification of flavonoid compounds have been applied correctly using samples that have been handpicked by students. All students successfully carried out project assignments with high grades. Students have practiced the analysis of organic compounds well, and no problems were found during the lecture [23]. Student competence in the field of organic compound analysis is well achieved. Project-based innovative learning resources are very suitable to be used for active learning $[24,24]$. It is recommended that this learning can also be applied to other fields of science that demand increased knowledge and skills.

\section{CONCLUSION}

Project-based innovative learning resources for teaching Organic Analytical Chemistry have been developed according to the KKNI curriculum. Learning resources consist of three project packages, equipped with multimedia examples of project implementation and supporting tools that can guide students to learn organic analysis. Learning resources developed effectively facilitate students' active learning to achieve competence in the field of organic analysis. Students succeed in 
planning and carrying out a flavonoid analysis project from plant samples. Analytical skills are formed, learning outcomes are high as an indicator that student competence in the field of organic analysis is achieved. The learning resources of this research finding are suitable to be used to teach Organic Analytical Chemistry during the Covid-19 Pandemic. This strategy needs to be adopted for teaching science fields that demand knowledge and skills.

\section{ACKNOWLEDGMENT}

Research funding from The Directorate of Research and Community Service, Deputy for Strengthening Research and Development, Ministry of Research and Technology / National Research and Innovation Agency, in

accordance with the Community Service Program Implementation Contract No 130/SP2H/LT/DRPM/2021.

\section{REFERENCES}

[1] Garg N K. How organic chemistry became one of UCLA's most popular classes. (2019), J Biol Chem. 294(46), 17678-17683. doi: 10.1074/jbc.AW119.008141

[2] Carey F A and Giuliano R M (2011) Organic Chemistry. $8^{\text {th }}$ ed McGraw-Hill, New York

[3] Richards-Babb M, Curtis R, Georgieva $Z$ and Penn J H. (2015) Student Perceptions of Online Homework Use for Formative Assessment of Learning in Organic Chemistry. J Chem Educ. 92(11),1813-1819. 10.1021/acs.jchemed.5b00294

doi:

[4] Dhama K, Khan S, Tiwari R, Sircar S, Bhat S, Malik Y S, Singh K P, Chaicumpa W, BonillaAldana D K and Rodriguez-Morales AJ. (2020) Coronavirus Disease 2019-COVID-19. Clin Microbiol Rev. 33(4), e00028-20. doi: 10.1128/CMR.00028-20

[5] Purba J, Situmorang M and Silaban R, (2019), The Development and Implementation of Innovative Learning Resource with Guided Projects for the Teaching of Carboxylic Acid Topic, Indian $J$ of Pharmaceutical Education and Research, 53(4), 603-612. DOI: 10.5530/ijper.53.4.121

[6] Mallah S I, Ghorab O K, Al-Salmi S, Abdellatif O S, Tharmaratnam T, Iskandar M A, Sefen J A N, Sidhu P, Atallah B, El-Lababidi R and Al-Qahtani M (2021) COVID-19: breaking down a global health crisis. Ann Clin Microbiol Antimicrob. 20(1), 35. doi: 10.1186/s12941-021-00438-7

[7] Sinaga M, Situmorang M, and Hutabarat W (2019), Implementation of Innovative Learning Material to Improve Students Competence on Chemistry.
Indian $J$ of Pharmaceutical Education and Research. 53(1):28-41. DOI: 10.5530/ijper.53.1.5

[8] Styers M L, Van Zandt P A, and Hayden K L (2018) Active Learning in Flipped Life Science Courses Promotes Development of Critical Thinking Skills. CBE life sciences education, 17(3), ar39. https://doi.org/10.1187/cbe.16-11-0332

[9] Minh T N, Xuan T D, Tran H D, Van T M, Andriana Y, Khanh T D, Quan N V, and Ahmad A. (2019) Isolation and Purification of Bioactive Compounds from the Stem Bark of Jatropha podagrica. Molecules. $24(5), \quad 889 . \quad$ doi: 10.3390/molecules24050889

[10] Ivanović M, Islamčević Razboršek M, and Kolar M. (2020) Innovative Extraction Techniques Using Deep Eutectic Solvents and Analytical Methods for the Isolation and Characterization of Natural Bioactive Compounds from Plant Material. Plants (Basel). 9(11), 1428. doi:10.3390/plants9111428

[11] Mottaghipisheh J, Iriti M. and Sephadex ${ }^{\circledR}$ LH-20, (2020) Isolation, and Purification of Flavonoids from Plant Species: A Comprehensive Review. Molecules. $\quad 25(18), \quad 4146 . \quad$ doi: 10.3390/molecules25184146

[12] Ullah A, Munir S, Badshah S L, Khan N, Ghani L, Poulson B G, Emwas A H, and Jaremko M. (2020) Important Flavonoids and Their Role as a Therapeutic Agent. Molecules. 25(22), 5243. doi: 10.3390/molecules25225243

[13] Hou M, Hu W, Xiu Z, Jiang A, Men L, Hao K, Sun X, and Cao D. (2019) Preparative Purification of Total Flavonoids from Sophora tonkinensis Gagnep. by Macroporous Resin Column Chromatography and Comparative Analysis of Flavonoid Profiles by HPLC-PAD. Molecules. 24(17), 3200. doi: 10.3390/molecules24173200

[14] UNIMED, (2016) Universitas Negeri Medan, Kurikulum Berorientasi Kerangka Kualifikasi Nasional Indonesia (KKNI), Indonesian National Qualifications Framework Curriculum, Universitas Negeri Medan, UNIMED Medan, Indonesia,

[15] Situmorang M, Sitorus M, Hutabarat W, and Situmorang Z (2015) The Development of Innovative Chemistry Learning Material For Bilingual Senior High School Students in Indonesia, International Educational Studies; 8(10), 72-85

[16] Situmorang, M., Purba, J., and Silaban, R., (2020), Implementation of an Innovative Learning Resource With Project to Facilitate Active Learning to Improve Students' Performance on Chemistry, Indian $J$ of Pharmaceutical Education and Research, 54(4), 905-14. DOI: 10.5530/ijper.54.4.184 
[17] Yu H, Zhang J, and Zou R. (2021) A Motivational Mechanism Framework for Teachers' Online Informal Learning and Innovation During the COVID-19 Pandemic. Front Psychol. 12, 601200. doi: 10.3389/fpsyg.2021.601200

[18] Alhathli M, Masthoff J, and Beacham N. (2020) Adapting Learning Activity Selection to Emotional Stability and Competence. Front Artif Intell. 3, 11. doi: 10.3389/frai.2020.00011

[19] Juliandini, G., Situmorang, M., and Muchtar, Z., (2020), An Innovative Chemistry Learning Material With Project and Multimedia to Developed Students Thinking Skill on the Teaching of Anion Analysis, Education and Humanities Research, volume 488: 97-103. https://doi.org/10.2991/assehr.k.201124.024

[20] Situmorang M, Sinaga M, Purba J, Daulay SI, Simorangkir M, Sitorus M, and Sudrajat A. (2018), Implementation of Innovative Chemistry Learning Material With Guided Tasks to Improve Students' Competence. Journal of Baltic Science Education.; 17(4), 535-550, http://oaji.net/articles/2017/9871533708387.pdf

[21] Nainggolan B, Sitorus M, Hutabarat W, and Situmorang M, (2020), Developing Innovative Chemistry Laboratory Workbook Integrated with Project-based Learning and Character-based Chemistry, International Journal of Instruction 13(3), 895-908

[22] Situmorang, H N, Purba S and Situmorang M (2020) Learning Innovations During the Pandemic COVID-19 for Teaching of Automotive Industrial Management, Advances in Social Science, Education and Humanities Research, volume 488, 261-267.

https://doi.org/10.2991/assehr.k.201124.055

[23] Sari D P, Sitorus M, Situmorang M, and Sudrajat A (2020) Implementation of Project-Based Learning Resources with Multimedia to Improve Student Learning Outcomes in Teaching Cation Analysis, Education and Humanities Research, volume 488: 120-126. https://doi.org/10.2991/assehr.k.201124.028

[24] Samosir R A, Bukit J, Situmorang M, and Simorangkir M, (2020) Implementation Of Innovative Learning Material With Project To Improve Students' Performance In The Teaching Of Complexometric Titration, PervasiveHealth: Pervasive Computing Technologies for Healthcare, 1, 375-384. https://eudl.eu/doi/10.4108/eai.12-102019.2296541

[25] Rizki R, Hernando H, Situmorang M, and Tarigan S (2020) The Development Of Innovative Learning Material With Project And Multimedia For Redox Titration, PervasiveHealth: Pervasive Computing
Technologies for Healthcare, 1, 385-393. https://eudl.eu/doi/10.4108/eai.12-102019.2296376 